\title{
Giant pituitary incidentaloma
}

\author{
Claudia Matta-Coelho, ${ }^{1}$ Rui Ramos, ${ }^{2}$ Rui Almeida, ${ }^{2}$ Olinda Marques ${ }^{1}$
}

'Department of Endocrinology, Hospital de Braga, Braga, Portugal

${ }^{2}$ Department of Neurosurgery, Hospital de Braga, Braga, Portugal

Correspondence to Dr Claudia Matta-Coelho, claudiadmcoelho@gmail.com

Accepted 18 June 2018

\section{DESCRIPTION}

A 78-year-old woman, independent, with medical history of hypertension, dyslipidaemia and bilateral cataract surgery. The patient underwent a head CT after a traumatic brain injury where a giant pituitary incidentaloma of $60 \mathrm{~mm}$ in the largest diameter was found. The patient mentioned decreased left eye acuity for the past 20 years, with no complaints of headaches or diplopia. The physical examination was unremarkable with no stigmata of endocrine disease. Anterior pituitary hormonal profile was normal. Additional MRI showed an extensive infiltrative lesion, $60 \times 40 \mathrm{~mm}$, with cavernous and sphenoidal sinus invasion, suprasellar extension and left optic nerve encapsulation (figures 1 and 2). Visual field campimetry revealed left amaurosis and right inferior temporal quadrantanopia. A nasal endoscopic biopsy was performed and the histopathology was compatible with pituitary adenoma with rare cells staining positive for adrenocorticotropic hormone and alpha subunit. Cytological atypia was absent and the Ki67 index was extremely heterogeneous with some areas having a Ki67 index below 1\% and others a Ki67 index above $40 \%$. The surgical team discussed the risks and benefits of surgery with the patient and family. The decision was made to defer surgery and maintain expectant observations with periodic hormonal, imaging and visual assessments.

Giant pituitary adenomas are defined as lesions larger than $4 \mathrm{~cm}$ maximum diameter. ${ }^{1}$ Clinical judgement should be used in determining the

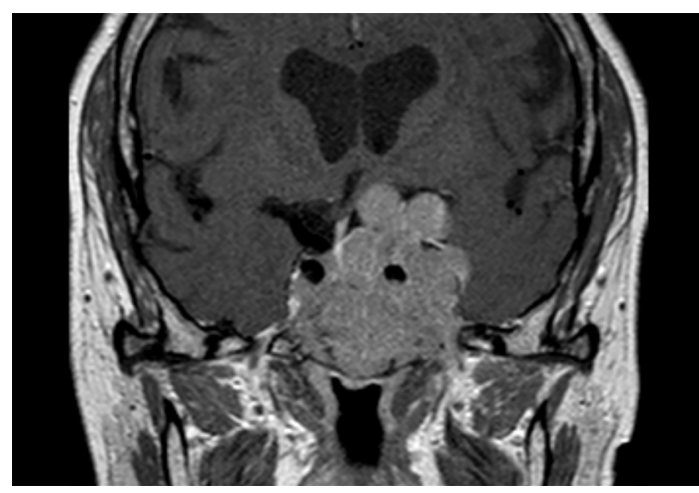

Figure 1 T1 coronal (1) and sagittal (2) weighted images with gadolinium enhancement demonstrating an extensive lesion, centred on the sellar cavity with parasellar expression, and extending to the middle floor of the skull base and to the anterior floor. It has also a suprasellar expression, causing a deviation of the optic chiasm to the right.

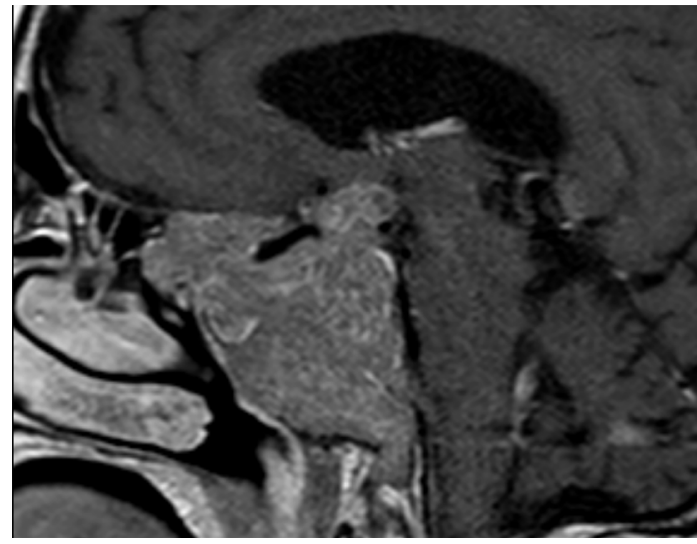

Figure 2 T1 coronal (1) and sagittal (2) weighted images with gadolinium enhancement demonstrating an extensive lesion, centred on the sellar cavity with parasellar expression, and extending to the middle floor of the skull base and to the anterior floor. It has also a suprasellar expression, causing a deviation of the optic chiasm to the right.

appropriate therapy for these adenomas: surgical resection, radiation therapy or expectant observation. Management remains a significant challenge despite improved surgical techniques, due to the risk of postoperative life-threatening complications, ${ }^{2}$ whereas the results of radiation therapy are inconsistent. ${ }^{3}$ In this case, potential risks of treatment outweighed possible benefits attending to the patient's age, absence of life-threatening symptoms, longevity of the disease and tumour characteristics.

Learning points

- Facing a patient with visual impairment, clinicians should consider pituitary adenoma as a differential diagnosis.

- Treatment of non-functioning pituitary adenomas consists of surgery, radiotherapy or expectant observation.

- Management of large pituitary adenomas may be a challenge and requires an individualised strategy depending on clinical, radiological and pathological criteria.

Contributors $\mathrm{CM}-\mathrm{C}$ has written the manuscript. The images were selected and the manuscript reviewed by RR. The manuscript was reviewed and corrected by OM and RA.

Funding The authors have not declared a specific grant for this research from any funding agency in the public, commercial or not-for-profit sectors.

Competing interests None declared.

Patient consent Obtained. 


\section{Images in...}

Provenance and peer review Not commissioned; externally peer reviewed.

\section{REFERENCES}

1 Melmed S. Pathogenesis of pituitary tumors. Nat Rev Endocrinol 2011;7:257-66.
2 Cappabianca P, Cavallo LM, Solari D, et al. Size does not matter. The intrigue of giant adenomas: a true surgical challenge. Acta Neurochir 2014;156:2217-20.

3 Goel A, Nadkarni TD. Giant pituitary tumors: a study based on surgical treatment of 325 cases. Int J Neurol Neurosurg 2009;1:39-52.

Copyright 2018 BMJ Publishing Group. All rights reserved. For permission to reuse any of this content visit http://group.bmj.com/group/rights-licensing/permissions.

BMJ Case Report Fellows may re-use this article for personal use and teaching without any further permission.

Become a Fellow of BMJ Case Reports today and you can:

- Submit as many cases as you like

Enjoy fast sympathetic peer review and rapid publication of accepted articles

- Access all the published articles

Re-use any of the published material for personal use and teaching without further permission

For information on Institutional Fellowships contact consortiasales@bmjgroup.com

Visit casereports.bmj.com for more articles like this and to become a Fellow 